У, $\triangle \mathrm{K} 347.1$

ББК 67.404.0

DOI 10.22394/1682-2358-2019-3-24-28

A.R. Kusaeva, post-graduate student of the Financial University under the Government of the Russian Federation

\section{COMPARATIVE \\ ANALYSIS \\ OF PECULIARITIES \\ OF ELECTRONIC \\ TRANSACTIONS \\ CONCLUSION \\ IN RUSSIA \\ AND GERMANY: \\ LEGAL ASPECTS}

The legal issues related to the transactions that are carried out via the global Internet are considered. Types of electronic transactions, as well as their mechanisms of legal regulation are studied. A comparative analysis of legal regulation mechanisms for electronic transactions in Russia and Germany is drawn.

Key words and word-combinations: electronic transaction, electronic commerce, electronic signature, Internet network.
A.P. KусаеВа, аспирант Финансовоzо университета при Правительстве РФ (email: akusayeva@mail.ru)

\section{СРАВНИТЕАЬНЫЙ АНААИЗ ОСОБЕННОСТЕЙ ЗАКАЮЧЕНИЯ ЭАЕКТРОННЫХ САЕ $\Lambda$ ОК В РОССИИ И ГЕРМАНИИ: ПРАВОВЫЕ АСПЕКТЫ}

\footnotetext{
Аннотация. Рассматриваются правовые вопросы, связанные со сделками, которые совершаются посредством глобальной сети «Интернет». Исследуются виды электронных сделок, а также механизмы их правового регулирования. Проводится сравнительный анализ механизмов правового регулирования электронных сделок в России и ФРГ.

Ключевые слова и словосочетания: электронная сделка, электронная торговля, электронная подпись, Интернет.

овременный этап становления системы права стран мира характеризуется размичными преобразованиями. Применение инновационных средств коммуникации, особенно глобамьной сети «Интернет», способствовацо появлению новой области правоотношений, которые связаны с обменом данных посредством Интернета.

В связи с этим актуацьными явцяются правовые аспекты сделок, которые совершаются в электронном виде. Электронная сделка - это продажа ими приобретение
}

24 Bulletin of the Volga Region Institute of Administration • 2019. Vol. 19. № 4 
товаров и услуг компаниями, частными домохозяйствами или частными миџами через Интернет. Интернет-рынок в России выполняет свои функции, но нормы гражданского законодательства Российской Федерации не соответствуют основным принципам его формирования и деятельности.

Целесообразно рассмотреть положительный зарубежный опыт правового регулирования данной сферы правоотношений. Проанализируем опыт Федеративной Республики Германия, так как это одна из первых стран, где распространены электронные сделки, в частности, электронная торговця. Германское гражданское право является образцом дия развития российского гражданского права. Современные реформы гражданского права в России во многом опираются на опыт германского права. Кроме того, Германия стала одним из первых государств в Европе и вторым в мире, где принят Закон об электронной поАписи.

Электронная торговмя в Германии сегодня приобрела значительный объем. Чем больше увеличивается валовый доход страны, тем больше растет оборот Аистанционных продаж. Согласно данным Федерального союза электронной торговци (bevh), доля продаж через Интернет составцяет почти 13\% от общего объема розничной торговми [1] .

В ФеАеративной Республике Германия 21 декабря 2001 г. вступил в силу закон, регулирующий правовые аспекты слелок, совершаемых в электронном виде [2], который упростил процеАуру получения согласия со стороны пользователей. Кроме того, интернет-продавцы получили возможность таким образом повысить свою правовую безопасность. После принятия данного закона в Германии, как и во всей Европе, подтверждение отправцяется по электронной почте или нажатием кнопки прямо на сайте. Новый закон преАусматривает более совершенные механизмы защиты прав потребителя, такие как ограничение времени хранения информации о пользователях и ее использования.

В Российской Федерации отсутствует отАельный закон, регулирующий правовые аспекты сделок, совершаемых в электронном виде. ОАним из критериев признания сделок, совершенных в электронном виде, явцяется наличие электронно-цифровой подписи (ЭЦП). К сожалению, применение технологий в сфере заключения сделок на практике вызывает определенные затруднения.

В соответствии с Гражданским кодексом Российской ФеАераџии, сделки могут совершаться в устной или письменной форме. Устная слелка заключается, если законом или соглашением сторон не установлена письменная форма (простая ици нотариацьная) в соответствии с п. 1 ст. 158 и п. 1 ст. 159 ГК РФ. Письменная форма бывает двух видов: простая и нотариальная. Письменные сделки заключаются путем составцения единого документа, который выражает содержание такой сделки. Его подписывают миџа, совершающие слелку или Аолжкным образом уполномоченные на это (п. 1 ст. 160 ГК РФ) [3].

Гражданский кодекс Российской Федерации сегодня позволяет использовать при совершении сделок факсимильную подпись с помощью среАств механического копирования или электронно-цифровую подпись. Аоговор в письменной форме может быть заключен путем составления документа, поАписанного сторонами, а также путем обмена данными «посреАством почтовой, 
темеграфной, теметайпной, телефонной, эмектронной или иной связи, позвомяющей достоверно установить, что документ исходит от стороны по договору» (п. 2 ст. 434 ГК РФ) [3]. Целью составления данного документа явмяется обеспечение правовых условий использования электронной цифровой подписи в электронных документах. При соблюдении норм этого закона электронная подпись признается равнозначной собственноручной подписи в документе на бумажном носителе [4], следовательно, электронная подпись является одним из реквизитов договора (соглашения), который заключается электронным способом. Применение Аанной технологии на практике вызывает множество затруднений, так как использование ЭЦП не гарантирует защиты от неправомерного доступа к системе. Эта проблема обусловлена пробелами законоАательства, направленного Аишь на одну технологию идентификации, которая считается универсальной. Отметим, что такое авторитетное учреждение, как Центральный Банк РФ, использует несколько альтернативных технологий, несмотря на участие в разработке Закона «Об эмектронно-цифровой подписи». Кроме того, проблема заключается в критериях признания иностранных ЭЦП и иностранных сертификатов о действительности подписи. Иностранный сертификат, подтвержАающий подлинность ключа подписи, признается на территории Российской Федерации в следующих случаях:

- он должен быть удостоверен в соответствии с законодательством госуАарства, где он идентифиџирован;

- выполнены процедуры признания юридической силы иностранных документов, установленных в Российской Федерации.

В ст. 18 Закона «Об электронно-цифровой подписи» оговариваются данные условия [4], но не указывается, в каких случаях электронно-цифровая подпись может рассматриваться как замена традиџионной подписи (ст. 18 данного Закона устанавливает требования по признанию юридической силы иностранных документов, а не подписей). Следовательно, в России отсутствуют механизмы признания иностранных сертификатов электронно-цифровой подписи.

Рассмотрим правовые аспекты ЭЦП на примере Германии.

Закон «О цифровой подписи» (Signaturgesetz) в Германском законодательстве является ст. 7 Закона «О регулировании основных условий предоставмения информационных и коммуникационных услуг» [5]. Аля исполнения Аанного Закона правительством Германии издано Постановление о цифровой подписи (Signaturverordnung) [5].

В соответствии с определением, данным в $\$ 2$ Закона «О цифровой подписи», электронная подпись - это «созданная с помощью частного кАюча печать к цифровым данным, которая с помощью соответствующего открытого кАюча, снабженного сертификатом кмюча подписи, выданным сертифицирующим центром или государственным учреждением в соответствии с $\$ 3$, позволяет определить владельца ключа подписи и подлинность Аанных» [5]. Вводя в оборот технологию цифровых подписей, правительство планировало создать инфраструктуру сертифиџирующих центров, на которые возмагаются задачи функционирования технологии цифровых подписей, то есть удостоверение мичности, создание ключей для владельцев и прочее. 
Аля повышения безопасности предусмотрена строгая процедура миџензирования деятельности сертифиџирующих џентров. Аиџензирование проводится правительственными службами. Сертифиџирующий центр получает миџензию в случае доказанной способности соблюдения предписанных Законом и Постановлением норм безопасности. Кроме того, в Аальнейшем правительственные органы регулярно проводят проверки выполнения сертифицирующим центром требований безопасности. Если по результатам проверки Аеятельность центра сертификации перестанет отвечать требованиям безопасности, а недостатки полностью не устранены в течение установленного правительством срока, то миџензия отменяется.

Правительственные службы обязаны вести базу данных с информацией обо всех мицензированных сертифищирующих центрах, в частности, в базу Аанных должны быть включены сведения об их публичных сертифицирующих ключах. Выдача миџензий и сертификатов сертифиџирующим џентрам, а также надзор за соблюдением положений Закона «О цифровой подписи» и Постановления о цифровой подписи, согласно Закону «О цифровой подписи», является обязанностью полномочного государственного органа, указанного в \66 Закона о телекоммуникациях, то есть Ведомства телекоммуникаций и почты (Regulierungsbehorde fur Telekommunikation und Post). В соответствии с абз. $5 \$ 4$ Закона о цифровой подписи уполномоченное государственное учреждение издает сертификат для ключа подписи [5]. Следовательно, создается иерархия сертификатов. Государственное учреждение своей подписью удостоверяет подпись сертифиџирующего џентра, а тот своей подписью подтверждает подписи пользователей.

Согласно германскому гражданскому праву, предписания о форме сделки Аолжны обеспечивать следующие функции:

1. УАостоверение заключения сделки (Abschlussfunktion).

2. Функцию удостоверения действительности (Echtheitsfunktion).

3. Функцию предупреждения (Warnfunktion).

4. Функцию идентифицирования (Identitatsfunktion).

5. Аоказательственную функцию (Beweisfunktion).

Практика применения электронных сделок в Германии находится на подъеме. Существует множество правовых норм, на которые предприниматецям необходимо обратить внимание, но эти положения становятся все более понятными и простыми. В частности, прогрессивная гармонизаџия законодательства ЕС приносит долгожАанную синхронизацию межАу разАичными юрисаикџиями [5]. МежАународные операџии по эмектронной коммерџии становятся проще и эффективнее (по крайней мере, в предеках ЕС). В будущем ЕС намерен внести дополнительные изменения в правовой режим и добиться более широкой стандартизации национального права стран - чиенов ЕС.

В России потенциальные пользователи электронной торговли больше общаются в соџиальных сетях, чем совершают покупки. В Германии же популярность электронных слелок значительно выше, чем у соџиальных сетей [6].

Изначально почти все положения электронной коммерџии складывались в пользу потребителя; сегодня эта тенденция изменилась: некоторые новые пра- 
вила (например, ограничение права отмены договора или стоимость обратной пересылки товара в случае отмены) благоприятствуют предпринимателям, а не потребитемям.

Закцючение сАелок в электронной форме прежде всего Аолжно способствовать ускорению процесса передвижения товаров в России. Необходимо принять правовые нормы, регулирующие все сферы электронных сделок [7] . Развитие правоотношений в области гражданско-правовых слелок, заключаемых в электронной форме, находится на начальном этапе, что свидетельствует об отсутствии эффективной правовой базы в Аанной сфере [8] .

Итак, в Российской Федерации одной из главных проблем, связанных с электронными сделками, явмяется отсутствие отдельного нормативного правового акта, регулирующего проџедуру и порядок совершения сделок в Интернете. Следствием этого является недоверие со стороны клиентов (инвесторов, возможных покупателей) и снижение темпов развития. Предпринималась попытка создания подобного нормативного правового акта, однако проект так и не вступия в законную силу. Аля устранения противоречий предлагается принять самостоятельный закон, который бы регулировац порядок заключения сделок в Интернете, а также внести изменения в Закон «Об электронной подписи» и Закон «Об электронных сделках» и рассмотреть опыт Германии по созданию и регулированию сертифицирующих центров.

\section{Библиографический список}

1. Der E-Commerce Verband. URL: https://www.bevh.org/

2. Gesetz über rechtliche Rahmenbedingungen für den elektronischen Geschäftsverkehr) Vom 14.12.2001, verkündet in BGB1 I Jahrgang $2001 \mathrm{Nr} .70$ vom 20.12.2001.

3. Гражданский кодекс Российской Федерации (ч. 1) от 30 нояб. 1994 г. № 51-Ф3 (в ред. от 23 мая 2018 г.) (с изм. и доп., вступ. в силу с 3 июня 2018) // СЗ РФ. 1994. № 32. Ст. 3301.

4. Об электронной подписи: Федер. закон от 6 апр. 2011 г. № 63-ФЗ // СЗ РФ. 2011. № 15. Ст. 2036.

5. Gesetz über Rahmenbedingungen für elektronische Signaturen (Signaturgesetz - SigG). 28.07.2017.

6. Гаврилин А.А. Исследование мирового рынка электронной коммерции за последние пять лет. Нижневартовск, 2017.

7. Хакимова И.В. Правовое регулирование электронной торговли в России. Курск, 2014.

8. Микаева А.С. Проблемы правового регулирования в сети Интернет и их причины // Актуальные проблемы российского права. 2016. № 9. 